\title{
The analysis of Ancol polder system as flood prevention infrastructure in Jakarta
}

\author{
Rian Mantasa Salve Prastica ${ }^{1, *}$ \\ ${ }^{1}$ Graduate Student, Civil Engineering Department, Universitas Indonesia, 16424, Depok, Indonesia
}

\begin{abstract}
Flooding in Jakarta is a common phenomenon that is caused by climate changes. One of the government's actions is building polders in Jakarta to prevent the flooding. However, these polders seem to not significantly affect it. This research aims to analyse Ancol Polder in North Jakarta as flood prevention infrastructure. This research uses Muskingum Cunge and O'Donnel and Muskingum Extended methods to analyse the hydrographs. This research analyses the performance of channel capacity by HEC-RAS modelling approach and observes its stabilization using GeoStudio 2012. The existing condition of the channel still accommodates the maximum outflow that enters the stream. Furthermore, its stability is safe in all of the reviewed STA in Pademangan Timur channel.
\end{abstract}

\section{Introduction}

Flooding is an annual disaster that hits Jakarta province. High levels of the flooding can drown housing, but housing can control the flood problem with a polder system. The floods that occurred in February 2002 really shocked the citizens of Jakarta. Approximately 10,000 hectares of settlements was flooded. Jakarta was paralyzed, even in some areas, water depths were up to four meters. The flood disaster resulted in a death toll that reached eighty people and direct economic losses of around Rp5.4 trillion. Furthermore, the indirect economic impact was estimated at approximately Rp4.5 trillion. Hence, it is a compulsory thing to make better policy by considering quantification analysis of the possible hazard and technical solutions about the analysis of the various vulnerabilities of societies, economy, and environment [1-3].

Basically, floods happen due to human activities [4]. People have to satisfy their daily needs. In order to fulfill them, they utilize land and make the disturbance towards the stability of the environment. It affects all objects that surround the environment, including human beings [5].

Large-scale flooding returned to 2007. Although it was not as bad as in 2002, the consequences were quite extensive. At least $60 \%$ of the Jakarta area was inundated and 150,000 residents had to leave their homes to evacuate. This incident made the citizens to not be able to move due to the brunt of the flood.

Considering the floods in Jakarta, there is an interesting phenomenon, namely the existence of one of the areas in North Jakarta which in recent years has not experienced

\footnotetext{
*Corresponding author: rian.mantasa@ui.ac.id, rianmantasasp@gmail.com
} 
flooding. It is an elite residential area namely Pantai Indah Kapuk. The public had pointed out that one of the causes of flooding is because this residential area elevates all of the land in that place so that water cannot enter at all. Later, that opinion was successfully ignored, because this area uses Polder System in its flood control effort.

By using this polder system, one area will keep the amount of water even in the rainy season. Conditions like this at once liberate the area from the threat of flooding. On the other hand, during the dry season, the polder area keeps the water because this system requires the availability of a water retention basin. Therefore, this area will have the availability of water in the dry season.

In Jakarta, such a system is very suitable because the threat of land degradation is also quite large. Therefore, in addition to flood prevention, there should also be efforts to minimize the reduction of groundwater in this area. However, problems always arise every time. The polder system faces threats because of the increasing population and the development of infrastructure in Jakarta that makes land uses change from forest and agricultural domains become of people settlements [6]. Rapid land-use changes and increase in extreme rainfall events due to climate changes could potentially result in high flood risk [7, 8]. This will impact the performance and capacity of existing polder systems in Jakarta. For example, the capacity of drainage channels that cannot accommodate the discharge of rainfall due to silting, damaged dikes, and other problems such that this polder system cannot be optimum to cover the service area. One of the polders to be reviewed in this paper is the Ancol polder. This study aims to investigate the condition of Ancol polder as a flood prevention infrastructure in Jakarta.

\section{Study area}

Jakarta is located in the Ciliwung basin. The previous study shows that the Ciliwung River basin showed rising urbanization [9], decreasing green [10] and blue space, increasing river discharge $[11,12]$, and flooding events [9].

This research focuses on Ancol polder that is situated in the East Region of the River Flow System in Jakarta. Figure 1 depicts the original map of the East Region of the River Flow System in Jakarta, which is cited from Water Management Agency of Jakarta. The main drainage channels in the Ancol polder are Pademangan Timur and Pademangan Barat channels. Based on the boundary conditions set by the Dinas Tata Air, the Ancol Polder area in North Jakarta has the following boundary.

North : R. E. Martadinata St.

South : Angkasa Raya Landas Pacu Barat St.

West : Gunung Sahari Railway

East : Benyamin Sueb St.

This polder has 643.382 hectares of area and has five main rivers. They are Ancol River, Sentiong River, Mati Pademangan River, Pademangan Timur River, and Pademangan Barat River.

\section{Research method}

Hydrology analysis is conducted to analyse rainfall data. Laksana [13] employed several empirical formulae to compute the rainfall intensity. There are Sherman, Kimijima, Haspers, and Mononobe [14]. In this research, Mononobe method is employed to compute rainfall intensity. Flood routing analysis is analysed in the Pademangan Timur channel as the longest main river in the polder system. This channel is chosen according to the longest time concentration analysis by using Kirpich method [14]. Before flood routing is analysed, 
synthetic unit hydrograph will be analysed. The unit hydrograph (UH) is a well-known modelling tool to analyse flood hydrographs. The UH could be used as a mathematical description of a linear system [14-19]. In recent years, there are several applications of hydrological modelling that have been conducted [20-22]. The present study aims to carry out Gamma I method to analyse return period of flood hydrograph.

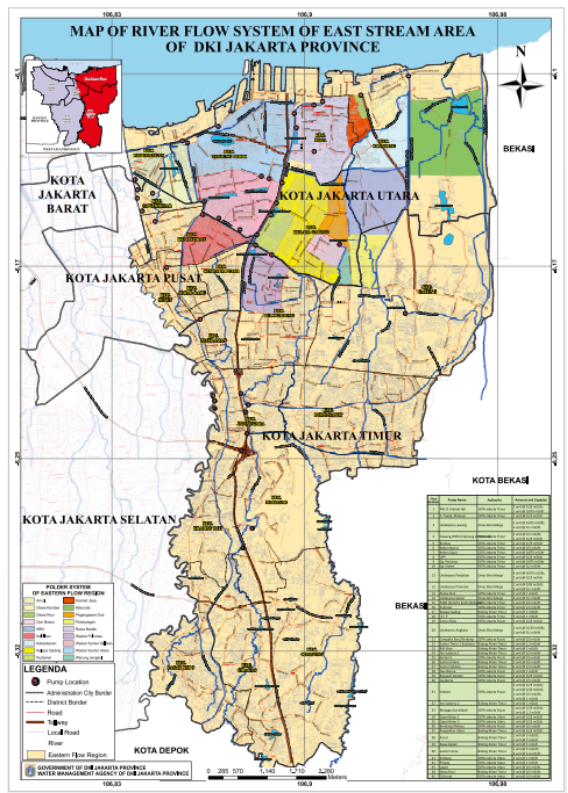

Fig. 1. Original map of east region of river flow system in Jakarta.

The next hydrology analysis will be conducted by employing two latest different methods of river flood routing. They are Muskingum Extented method and the combination of Muskingum Cunge and O'Donnel method. These methods then are compared to observe the differences. Saint-Venant equations govern the flow wave numerically in hydraulic routing. The strength of Muskingum method has no need of geometry data availability, but this method needs hydrograph flow in the upstream and downstream parts of the reviewed river. Cunge [23] developed the existing Muskingum method. The new method explains that the availability of the river's geometry data and river hydrographs can predict the flow hydrograph in every reviewed point along the river and the downstream part of the river. However, there should not be any lateral flows in the reviewed river. Khan [24] then developed Muskingum method to be Muskingum Extended method. Khan [24] stated that the result is more accurate than Muskingum method that was developed by O'Donnel [25].

The analysis of flow profile in Pademangan Timur channel is observed by employing HEC-RAS model. HEC-RAS is a widely used hydraulic model for river flow simulation which is developed by the Hydrological Engineering Center/ U. S. Army Corps of Engineers [26]. 1-D Saint-Venant equations govern the numerical solution. HEC-RAS can determine the flow characteristics with steady and unsteady conditions and provide a friendly graphical user interface of model results' visualization [27].

The final analysis is checking channels' slope stability. There are several numerical methods using finite element method that have been conducted by previous researchers, for example, Ishii et al. [28], Fawaz et al. [29], and Maji [30]. Göktepe [31] analysed slope stability during construction of a stadium on the Karabük University by employing three software like Plaxis, Geoslope, and Slide. This study will carry out Geoslope software to analyse the slope stability along Pademangan Timur channel. 


\section{Result and discussion}

\subsection{Hydrology analysis}

Rainfall analysis was conducted by using rainfall data from Tanjung Priok station for 14 years, from 1990 to 2003 . These years are selected because the study aims to analyse flood phenomenon in 2002. The return period rainfall was computed by Gumbel and Log Pearson type III methods. These results were accepted by Chi-squared analysis. Table 1 figures the analysis result for return period rainfall.

Table 1. Analysis of return period rainfall using Gumbel and Log Pearson type III methods.

\begin{tabular}{|c|c|c|}
\hline $\begin{array}{c}\text { Return period } \\
\text { rainfall }\end{array}$ & $\begin{array}{c}\text { Gumbel method } \\
(\mathbf{m m})\end{array}$ & $\begin{array}{c}\text { Log Pearson type III } \\
\text { method (mm) }\end{array}$ \\
\hline 2 years & 107 & 105 \\
\hline 5 years & 162 & 152 \\
\hline 10 years & 199 & 184 \\
\hline 25 years & 245 & 225 \\
\hline 50 years & 279 & 256 \\
\hline 100 years & 313 & 287 \\
\hline
\end{tabular}

Next, rainfall intensity was calculated by using Mononobe method. Figure 2 depicts the rainfall intensity graphic for all return period rainfall. There are three reviewed channels in Ancol polder. They are Pademangan Barat drainage channel, Pademangan Timur drainage channel, and Ancol River. Further analysis for HEC-RAS and Geo-slope modelling approach is chosen according to the longest concentration time among the channels. The concentration-time $(t c)$ was computed by using Kirpich method as shown in equation (1).

$$
t c=0.0195 x l^{0.77} x S^{-0.385}
$$

Where 1 represents slope length $(\mathrm{m})$ and $\mathrm{S}$ is slope $(\mathrm{m} / \mathrm{m})$. According to the Kirpich's analysis, Pademangan Timur's channel has the longest duration of concentration time, so it is chosen as the focus of the study in this research. Table 2 figures the concentration-time analysis of the three channels and figure 3 depicts the sketch of the study area of this research.

Table 2. Analysis of return period rainfall using Gumbel and Log Pearson type III methods.

\begin{tabular}{|c|c|c|c|}
\hline Channels & Channel's length (m) & Slope (m/m) & $\begin{array}{c}\text { Concentration time } \\
\text { (min) }\end{array}$ \\
\hline Pademangan Barat & 500.13 & 0.00045 & 45.3776 \\
\hline Pademangan Timur & 2365.91 & 0.00045 & 150.150 \\
\hline Ancol River & 980.82 & 0.00045 & 76.2205 \\
\hline
\end{tabular}

\subsection{Flood routing analysis}

Pademangan Timur channel's downstream part reaches Ancol River. There are three subcatchments that flow to Pademangan Timur channel. Figure 2 figures the sub-catchments of Pademangan Timur channel. 


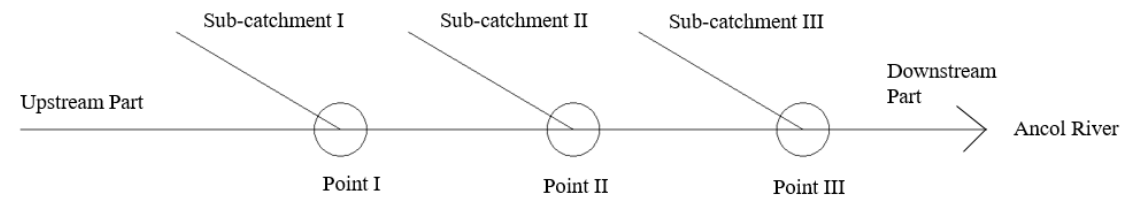

Fig. 2. Sub-catchments sketch of Pademangan Timur channel.

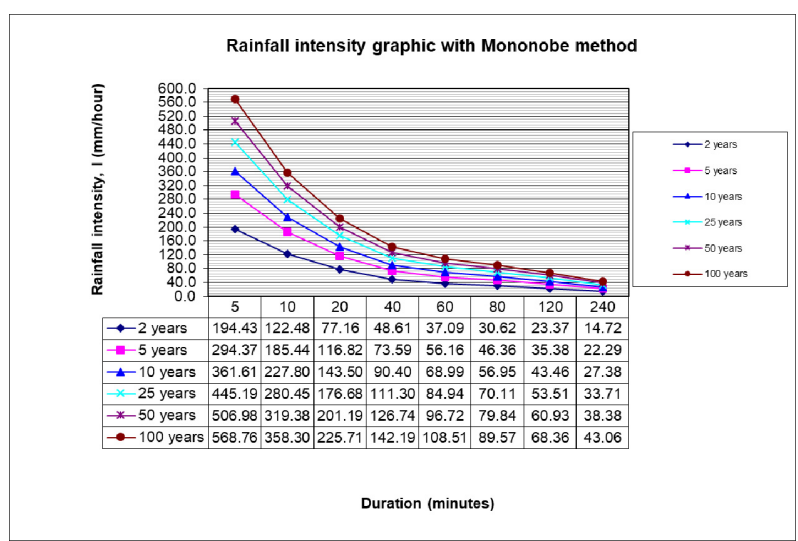

Fig. 3. Rainfall intensity.

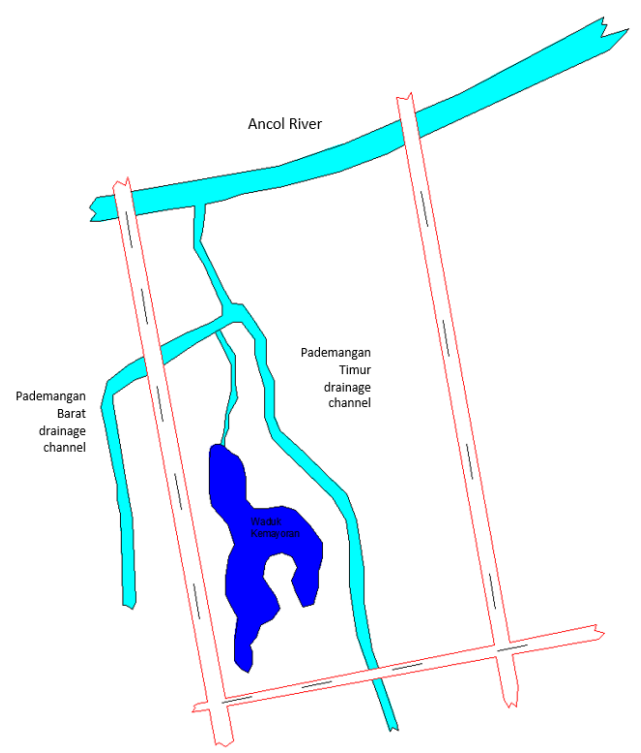

Fig. 4. Three main channels in Ancol polder.

Firstly, the synthetic unit hydrograph was calculated by employing Gamma I method for sub-catchment I, II, and III. Figure 5 depicts the result of the computation. Meanwhile, figure 6 shows the hydrograph analysis results example for sub-catchment I.

The next computation is river flood routing analysis. This study employs the combination of Muskingum Cunge and O'Donnel methods. Besides that, this study uses Muskingum Extended method to compare the previous method's result. Figure 7 depicts the example of inflow and outflow hydrograph for point I. Point II and point III were then analysed with the same methods. 

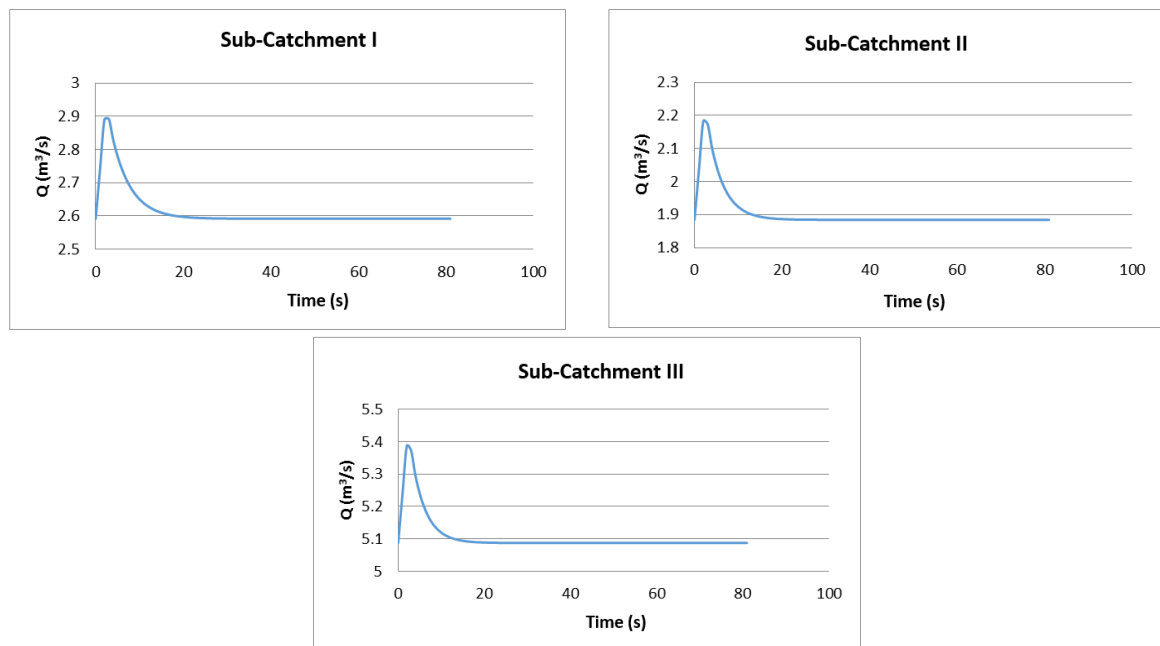

Fig. 5. Synthetic unit hydrograph based on Gamma I method.

The Muskingum Extended method was employed to compare the combination of Muskingum Cunge and O'Donnel methods. Muskingum Cunge and O'Donnel methods focus on three points to obtain the outflow to Ancol River. The final outflow to Ancol River is represented in point III analysis. Meanwhile, Muskingum Extended method will generate outflow to Ancol River directly. Figure 8 shows the comparison of outflow between Muskingum Cunge and O'Donnel methods and Muskingum Extended method. The highest gap is $6.19 \%$ in the third hour of outflow analysis. Muskingum Cunge and O'Donnel methods show $9.82 \mathrm{~m}^{3} / \mathrm{s}$, but Muskingum Extended gives $10.43 \mathrm{~m}^{3} / \mathrm{s}$. These methods almost have the same result in the sixth hour of analysis. Muskingum Cunge and O'Donnel methods and Muskingum Extended result $10.02 \mathrm{~m}^{3} / \mathrm{s}$ and $10.03 \mathrm{~m}^{3} / \mathrm{s}$ of outflow discharges, respectively.

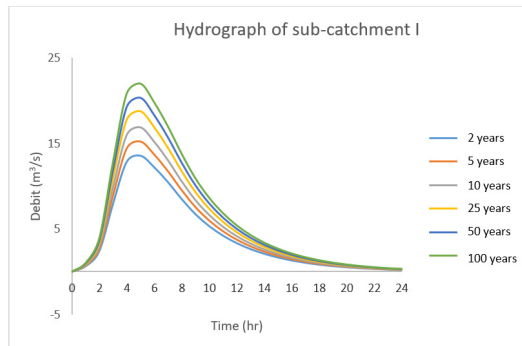

Fig. 6. Hydrograph of sub-catchments in Pademangan Timur channel.

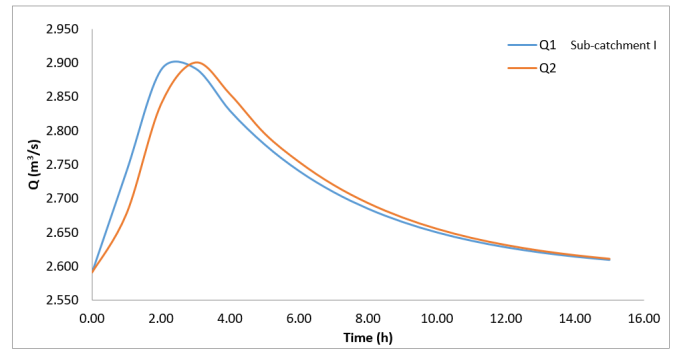

Fig. 7. Hydrograph of inflow-outflow in Point I.

\subsection{HEC-RAS modelling approach}

Channel flow's profile only focused on Pademangan Timur channel. This river's profile was cited from Water Management Agency of Jakarta. Table 3 and figure 9 show Pademangan Timur channel's profile from the reviewed upstream part to the downstream part that reaches the Ancol River. The detailed dimension would be used for HEC-RAS modelling to analysis the channel flow's profile. 


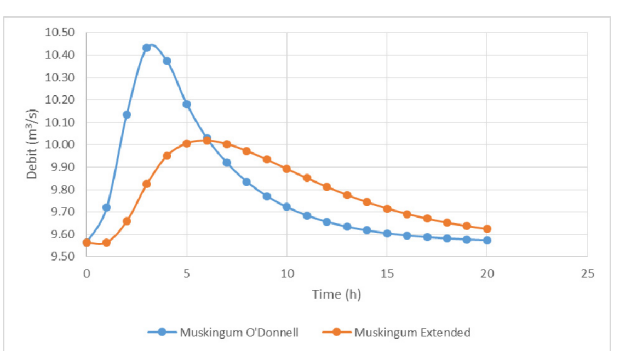

Fig. 8. Outflow to ancol river analysis.

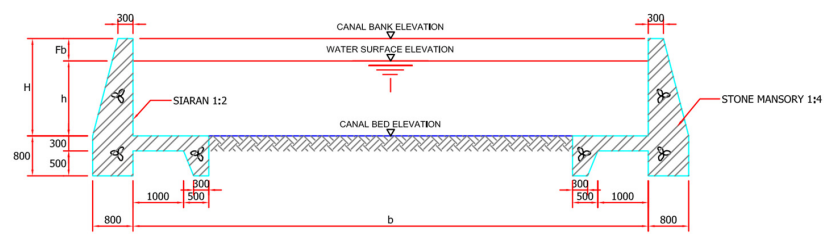

Fig. 9. Pademangan Timur channel dimension.

Table 3. STA profile in Pademangan Timur channel.

\begin{tabular}{|c|c|c|c|c|c|}
\hline \multirow{2}{*}{ Profile No. } & Length (m) & $\begin{array}{c}\text { Bed Width } \\
\text { Improvement } \\
(\mathbf{m})\end{array}$ & $\begin{array}{c}\text { Water } \\
\text { Depth } \\
(\mathbf{m})\end{array}$ & $\begin{array}{c}\text { Free } \\
\text { Board } \\
(\mathbf{m})\end{array}$ & \multirow{2}{*}{ H (m) } \\
\cline { 3 - 4 } & & $\mathbf{b}$ & $\mathbf{h}$ & $\mathbf{F b}$ & \\
\hline $0+00-6+24.3$ & 624.3 & 5.40 & 1.00 & 0.30 & 1.30 \\
\hline $6+24.3-10+48.8$ & 424.5 & 5.40 & 1.20 & 0.40 & 1.95 \\
\hline $10+48.8-23+34.3$ & 1285.5 & 6.20 & 1.20 & 0.40 & 1.95 \\
\hline $23+34.3-25+49.2$ & 214.9 & 13.20 & 2.30 & 0.50 & 2.30 \\
\hline $25+49.2-26+49.4$ & 100.2 & 14.50 & 2.30 & 0.50 & 2.30 \\
\hline $26+49.4-27+38.0$ & 88.6 & 14.80 & 2.30 & 0.50 & 2.30 \\
\hline
\end{tabular}

The flow characteristic is assumed to be a steady flow. The analysis would use return period rainfall that has been computed. The return period rainfall is for 2 years, 5 years, 10 years, 25 years, 50 years, and 100 years. Figure 10 depicts the result of HEC-RAS profile analysis for return period rainfall of 25 years.

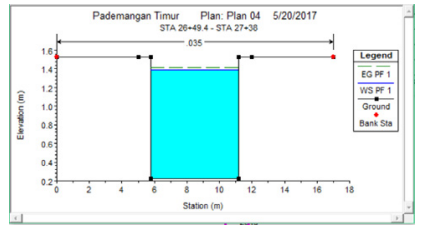

STA $0+00-$ STA $6+24,3$

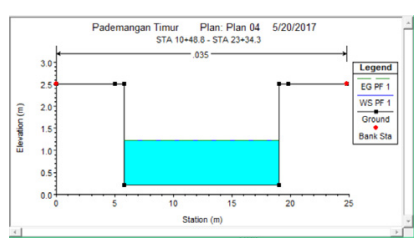

STA $23+34,3-$ STA $25+49,2$

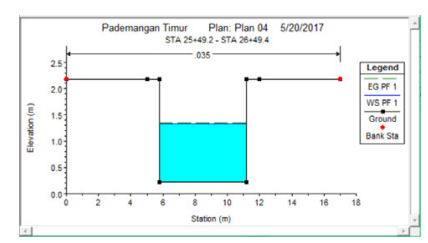

STA $6+24,3-$ STA $10+48,8$

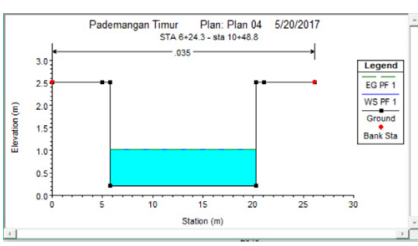

STA $25+49,2-$ STA $26+49,4$

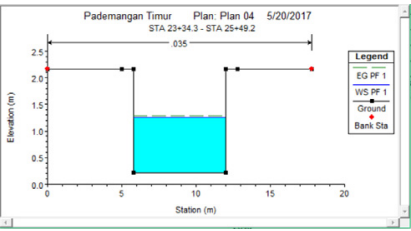

STA $10+48,8-$ STA $23+34,3$

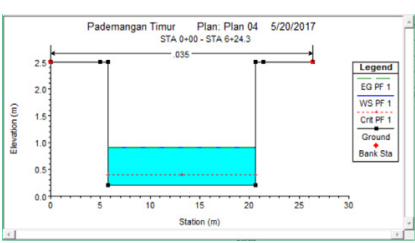

STA $26+49,4-$ STA $27+38,0$

Fig. 10. HEC-RAS analysis at Pademangan Timur channel profile for 25 years of return period rainfall. 
According to flow profile analysis by employing HEC-RAS modelling, all of the flows would not run off except for STA $0+00-$ STA $6+24.3$ with a return period rainfall of 100 years. However, the runoff does not influence the main channel condition. Besides that, channel design that uses 100 years of return period rainfall is not recommended as the basic design of drainage channel in Jakarta province.

\subsection{Water infrastructure stability analysis}

This study deals with the evaluation of the channel's dike stability and safety factor analysis by employing Geoslope. The water loading that is used in this analysis is the biggest discharge from return period rainfall analysis. This study uses 100 years of return period rainfall for all of the reviewed STA in Pademangan Timur channel, from STA $0+00$ to STA 27+38.0. Figure 11 depicts the result of slope stability analysis for all STA. The results show that the channel's dike condition in every STA in Pademangan Timur channel is still safe. The safety factors exceed 3.00 .
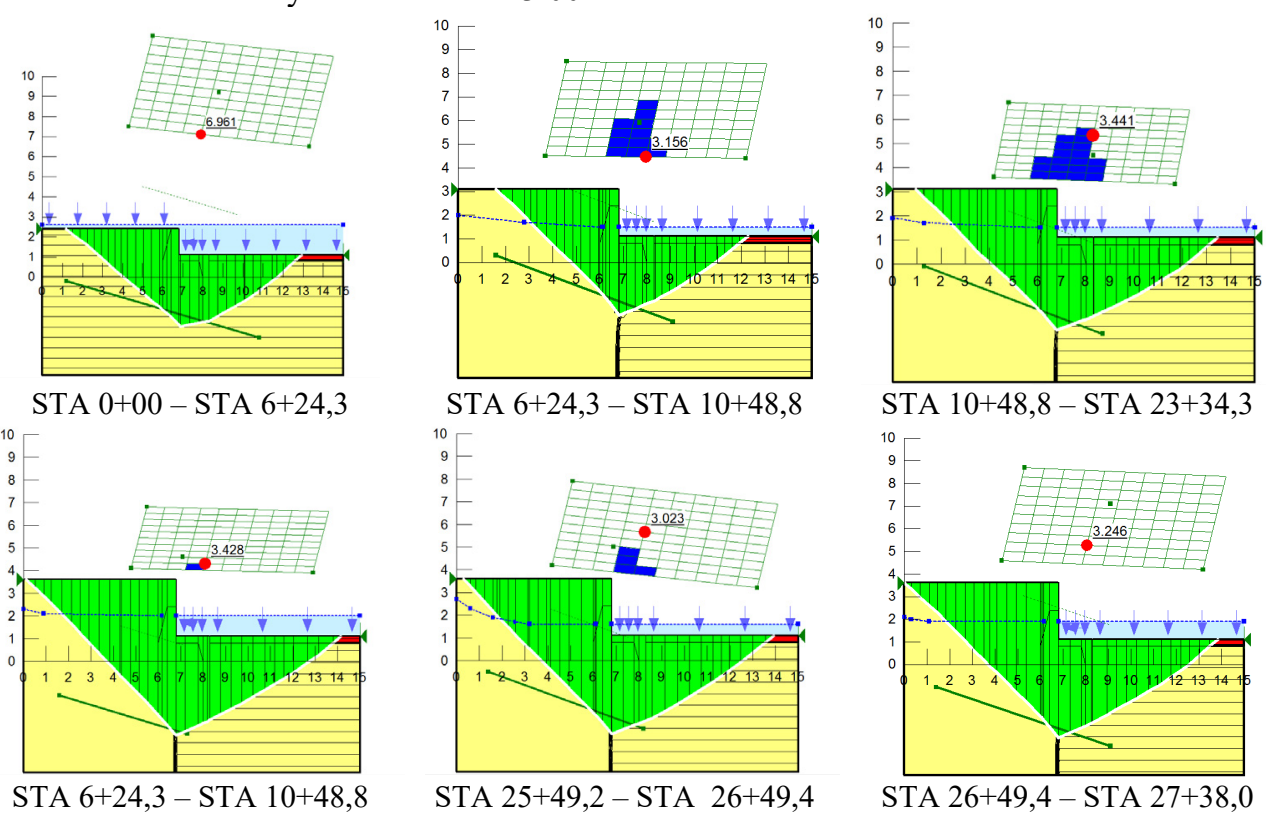

Fig. 11. Slope stability analysis at Pademangan Timur channel profile with 100 years of return period rainfall.

\section{Conclusion}

The study shows that all of the flows would not run off except for STA $0+00-$ STA $6+24.3$ with return period rainfall of 100 years. The flood phenomenon in 2002 that hit Jakarta did not impact the Ancol polder system in any way, especially in Pademangan Timur channel that is reviewed in the current study. Besides that, water infrastructure stability along Pademangan Timur channel does not have critical points. To conclude, both hydraulic, hydrology, and slope stability analysis of Ancol polder system could have prevented flooding in North Jakarta in 2002. Further analysis should be conducted to analyse the current condition. Furthermore, all of the polder systems nowadays in Jakarta should be reviewed to avoid worse impacts of possible flooding in the following years 
The author wishes to thank Hydraulic Laboratory of Engineering Faculty, University of Indonesia and Indonesia Endowment Fund for Education scholarship (LPDP), which is legislated by Indonesian Finance Ministry, as financial assistance to pursue a master program in Universitas Indonesia.

\section{References}

1. F. Klijn, H. Kreibich, H. de Moel, E. Penning-Rowsell, Adaptive flood risk management planning based on a comprehensive flood risk conceptualization, Mitigation and Adaptation Strategies for Global Change, 20 (6), pp. 845-864 (2015)

2. C.E. Haque, Risk assessment, emergency preparedness and response to hazards: The case of the 1997 Red River Valley flood, Canada, Natural Hazards, 21 (2-3), pp. 225245 (2000)

3. N. Kannan, Study of drawdown-drain discharge relationship and its application in design of cost effective subsurface drainage system in Mugogo swamp, Busogo, Rwanda, Water Resources Management, 22 (8), pp. 1113-1125 (2008)

4. N. Miharja, S. D. Panjaitan, S. Yattinah, "Analisis Kerawanan Dan Pengurangan Risiko Banjir di Kalimantan Barat Berbasis Sistem Informasi Geografi (SIG)", Jurnal Teknik Sipil (Universitas Tanjungpura Indonesia), 13 (2), pp. 379-396 (2013)

5. _ _ The Main Rules of Environmental Protection and Management, The Law of the Republic of Indonesia, No 32, Jakarta, Indonesia (2009)

6. D. Sugandi, The Effect of Socio-Economy towards Conservation at $\mathrm{Ci}$ Tanduy Watershed, Indonesian Journal of Geography, 45 (1), pp. 91-100 (2013)

7. S. $\mathrm{Ng}$, Governance beyond the government: Responding to a reactionary flood governance regime in Ayutthaya, Thailand, Habitat Int., Vol 52, p 11-19, (2015)

8. M. Guan, N. Sillanpää, H. Koivusalo, Modelling and assessment of hydrological changes in a developing 674 urban catchment. Hydrol. Process., 29, p 2880-2894, (2015)

9. F. Remondi, P. Burlando, D. Vollmer, Exploring the hydrological impact of increasing urbanization on a tropical river catchment of the metropolitan Jakarta, Indonesia. Sustain. Cities Soc., 20, p 210-221, (2016)

10. M. Ali, S. Hadi, B. Sulistyantara, Study on land cover change of Ciliwung downstream watershed with spatial dynamic approach. Procedia-Soc. Behav. Sci., 227, p 52-59, (2016)

11. Poerbandono, M. M. Julian, P. J. Ward, Assessment of the effects of climate and land cover changes on river discharge and sediment yield, and an adaptive spatial planning in the Jakarta region. Nat. Hazards 73, p 507-530, (2014)

12. R. M. S. Prastica, et al., Estimating Design Flood and HEC-RAS Modeling Approach for Flood Analysis in Bojonegoro City, IOP Conf. Ser. : Mater. Sci. Eng. 316012042 (2017)

13. P. J. Laksana, Rainfall characteristic on the slopes of Mount Merapi region, Journal of the civil engineering forum, Vol 1, No 3, p 43-50 (2015)

14. V. T. Chow, D.R. Maidment, Mays, L.W., Applied Hydrology, McGraw-Hill Book Co., Singapore, (1988)

15. L. K. Sherman, Stream flow from rainfall by the unit-graph method, Eng News Rec 108, p 501-505 (1932)

16. J. E. Nash, the forms of the instantaneous unit hydrograph, Int Assoc of Sci and Hydraul Div Proc ASCE 104 (HY2) p 262-276 (1957) 
17. J. C. Dooge, A general theory of the unit hydrograph, J Geophys Res 64 (2) p 241-256 (1959)

18. J. C. Dooge, Linear theory of hydrologic systems, Technical Bulletin No. 1468. US Department of Agriculture, Agricultural Research Service, Washington, DC (1973)

19. V. P. Singh, Hydrologic systems, vol 1, Prentice-Hall, Englewood Cliffs (1988)

20. Kuo S-F, Merkley GP, Liu C-W, Decision support for irrigation project planning using a genetic algorithm. Agril Water Manag 45 p 243-266 (2000)

21. A. Jain, S. Srinivasalu, R. K. Bhattacharjya, Determination of an optimal unit pulse response function using real-coded genetic algorithm, J Hydrol 303 p 199-214, (2005)

22. J. R. Rabuñal, J. Puertas, J. Suárez, D. Rivero, Determination of the unit hydrograph of a typical urban basin using genetic programming and artificial neural networks, Hydrol Process 21 p 476-485, (2007)

23. J. A. Cunge, On the subject of flood propagation computation method (Muskingum method). J Hydraul Res 7 (2), p 205-230, (1969)

24. M. H. Khan, Muskingum Flood Routing Model for Multiple Tributaries, Bangladesh Agricultural University, (1993)

25. T. O'Donnell, A direct three-parameter Muskingum procedure incorporating lateral inflow, Hydrol Sci J, 30 (4), p 479-496, (1985)

26. HEC - Hydrologic Engineering Center; USACE - U.S. Army Corps of Engineers. $H E C-R A S$ hydraulic reference manual, version 4.1. Davis: Institute of Water Resources, Hydrological Engineering Center, (2010)

27. V. A. Siqueira, V. S. Mino, M. B. Juan, C. Walter, M. V. L. Auder, G. V. T. Giovanni, Real-time updating of HEC-RAS model for streamflow forecasting using an optimization algorithm, Brazilian Journal of Water Resources, Vol 21, No 4, p 855870, (2016)

28. Y. Ishii, K. Ota, S. Kuraoka, R. Tsunaki, Evaluation of slope stability by finite element method using observed displacement of landslide, Landsl., v. 9, pp.335-348, (2012)

29. A. Fawaz, E. Farah, F. Hagechehade, Slope stability analysis using numerical modelling, Amer. Jour. Civil Engg., v. 2, pp. 60-67, (2014)

30. V. B. Maji, an insight into slope stability using strength reduction technique, Jour. Geol. Soc. India., v. 89, pp.77-81, (2017)

31. F. Göktepe, K. Inan, A comparison study between traditional and finite element methods for slope stability evaluations, Journal Geological Society of India, Vol. 91, p 373-379, (2018) 